\title{
Prevalence of hyperuricemia and relation of serum uric acid with cardiovascular risk factors in a developing country D Conen ${ }^{1}$, V Wietlisbach ${ }^{2}$, P Bovet ${ }^{2,3}$, C Shamlaye ${ }^{3}$, W Riesen ${ }^{4}$, F Paccaud ${ }^{2}$ and $M$ Burnier*1
}

\author{
Address: ${ }^{1}$ Division of Hypertension and Vascular Medicine, CHUV, Lausanne, Switzerland, ${ }^{2}$ University Institute of Social and Preventive Medicine, \\ Lausanne, Switzerland, ${ }^{3}$ Ministry of Health, Republic of Seychelles and ${ }^{4}$ Kantonalspital St Gallen, Switzerland \\ Email: D Conen - conend@uhbs.ch; V Wietlisbach - vincent.wietlisbach@inst.hospvd.ch; P Bovet - pbovet@seychelles.net; \\ C Shamlaye - shamlaye@seychelles.net; W Riesen - walter.riesen@ikch.ch; F Paccaud - fred.paccaud@inst.hospvd.ch; \\ M Burnier* - michel.burnier@chuv.hospvd.ch \\ * Corresponding author
}

Published: 25 March 2004

BMC Public Health 2004, 4:9
Received: 30 December 2003

Accepted: 25 March 2004

This article is available from: http://www.biomedcentral.com/I47I-2458/4/9

(C) 2004 Conen et al; licensee BioMed Central Ltd. This is an Open Access article: verbatim copying and redistribution of this article are permitted in all media for any purpose, provided this notice is preserved along with the article's original URL.

\begin{abstract}
Background: The prevalence of hyperuricemia has rarely been investigated in developing countries. The purpose of the present study was to investigate the prevalence of hyperuricemia and the association between uric acid levels and the various cardiovascular risk factors in a developing country with high average blood pressures (the Seychelles, Indian Ocean, population mainly of African origin).

Methods: This cross-sectional health examination survey was based on a population random sample from the Seychelles. It included I0II subjects aged 25 to 64 years. Blood pressure (BP), body mass index (BMI), waist circumference, waist-to-hip ratio, total and HDL cholesterol, serum triglycerides and serum uric acid were measured. Data were analyzed using scatterplot smoothing techniques and gender-specific linear regression models.
\end{abstract}

Results: The prevalence of a serum uric acid level $>420 \mu \mathrm{mol} / \mathrm{L}$ in men was $35.2 \%$ and the prevalence of a serum uric acid level $>360 \mu \mathrm{mol} / \mathrm{L}$ was $8.7 \%$ in women. Serum uric acid was strongly related to serum triglycerides in men as well as in women $(r=0.73$ in men and $r=0.59$ in women, $\mathrm{p}<0.00 \mathrm{I}$ ). Uric acid levels were also significantly associated but to a lesser degree with age, BMI, blood pressure, alcohol and the use of antihypertensive therapy. In a regression model, triglycerides, age, BMI, antihypertensive therapy and alcohol consumption accounted for about 50\% (R2) of the serum uric acid variations in men as well as in women.

Conclusions: This study shows that the prevalence of hyperuricemia can be high in a developing country such as the Seychelles. Besides alcohol consumption and the use of antihypertensive therapy, mainly diuretics, serum uric acid is markedly associated with parameters of the metabolic syndrome, in particular serum triglycerides. Considering the growing incidence of obesity and metabolic syndrome worldwide and the potential link between hyperuricemia and cardiovascular complications, more emphasis should be put on the evolving prevalence of hyperuricemia in developing countries. 


\section{Background}

The positive association between serum uric acid and cardiovascular diseases such as stroke or ischemic heart disease has been recognized since the 1950s and has been confirmed by numerous epidemiological studies since then [1-7]. However, whether uric acid is an independent risk factor for cardiovascular mortality is still disputed as several studies have suggested that hyperuricemia is merely associated with cardiovascular diseases because of confounding factors such as obesity, dyslipidemia, hypertension, use of diuretics and insulin resistance [8-10]. Moreover, there is still no well-established pathophysiological link between hyperuricemia and the development of cardiovascular complications.

Elevated serum uric acid levels are commonly seen in association with glucose intolerance, hypertension and dyslipidemia, a cluster of metabolic and hemodynamic disorders which characterize the so-called metabolic syndrome [11-15]. Studies performed in healthy volunteers as well as in subjects with asymptomatic hyperuricemia have suggested that the link between the metabolic syndrome and serum uric acid is related to the ability of insulin to decrease the clearance of uric acid in the renal proximal tubule resulting in an increase in serum uric acid levels [16]. Several population-based studies have also examined the influence of a number of cardiovascular risk factors or components of the metabolic syndrome on serum uric acid levels. Thus, elevated serum uric acid levels have been linked to hypertension, hyperinsulinemia, reduced physical activity, increased body mass index, increased alcohol consumption and decreased HDL cholesterol [11,13,14,16-22].

Most studies on uric acid have been performed in selected white populations of North America and Europe or entirely black populations from South Africa. In 1973, Klein et al studied a multiracial community in Evans County, Georgia, in order to examine the frequency distribution of serum uric acid and the relationship of serum uric acid levels with known coronary risk factors [23]. They found that the prevalence of hypertension was greater in hyperuricemic as compared to subjects without hyperuricemia in all race-sex groups. More recently, two studies have explored the relationship of serum uric acid with cardiovascular risk factors in a bi-racial community $[16,17]$. However, these latter investigations were conducted essentially in children and young adults. The prevalence of hyperuricemia has rarely been investigated in developing countries.

The purpose of the present study was to investigate the prevalence and the clinical correlates of hyperuricemia in a developing country, the Seychelles, a population mainly of African origin. A population-based health examination survey was conducted recently in this country. The study population represents a complete sample of the general population including elderly subjects.

\section{Methods}

\section{The Seychelles Heart Study II}

The Seychelles Heart Study II was a second survey to assess the cardiovascular risk factors and selective cardiovascular outcomes in the population of the Seychelles, a group of 115 islands lying in the Indian Ocean with a relatively high cardiovascular morbidity and mortality [24]. Indeed statistics, which are based on death certificates established by a doctor for all fatalities in the country, indicate that cardiovascular disease accounted for $37 \%$ of all deaths in 2003. The study was conducted between July and December 1994 . About $65 \%$ of the population of the Seychelles is of black descent, $10 \%$ of predominantly Caucasian and $5 \%$ of predominantly Indian or Chinese descent, the $20 \%$ remaining being mixed. The study was designed as a crosssection of the general population. It has been described in detail before [24]. A simple age- and sex-stratified random sample of the residents aged 25-64 years living on the principal island ( $89 \%$ of the total population) was included. Among the initial group of 1280 persons, 1226 were eligible and a total of 1059 participated the study, a response rate of $86 \%$. All participants have been submitted to a detailed questionnaire and a medical examination in the study centre between 8 a.m. and 10 a.m.

\section{Measures and cut-off points \\ Smoking}

Smoking habits were classified as followed: persons who did never smoke, ex-smokers designated persons who reported no current smoking but regular smoking in the past, occasional smokers referred to persons reporting non-daily consumption of cigarettes and regular smokers, currently smoking at least one cigarette per day.

\section{Weight and height and body mass index}

Height and body weight were measured with participants standing without shoes and heavy outer garments. Body mass index (BMI) was calculated as weight divided by height squared $\left(\mathrm{kg} / \mathrm{m}^{2}\right)$. Hip and waist were measured to the nearest $1 \mathrm{~cm}$.

\section{Alcohol habits}

Alcohol consumption was assessed in two stages. In the first, persons were categorised according to frequency of alcohol drinking: never, occasionally but less than once a week, once or twice a week, every other day and almost every day. Those declaring a consumption of at least one drink per week were further questioned about their weekly average consumption of the different alcohol beverages available. 


\section{Blood pressure}

Blood pressure (BP) was measured three times consecutively on the right arm with a standard sphygmomanometer, the subject being in a sitting position after at least 30 minutes of rest. Values, determined as the mean of the last two measurements, were recorded to the nearest $2 \mathrm{~mm}$ $\mathrm{Hg}$, and readings based on Korotkoff first and fifth base sounds. Participants were asked if they had taken drugs for high blood pressure within 2 weeks prior to the examination. Hypertension was defined as a diastolic BP $\geq 95$ and/ or current intake of antihypertensive medication.

\section{Diabetes}

The diagnosis of diabetes mellitus was considered when individuals reported to have been told by a doctor to have diabetes or tested positive for glycosuria. Presence of sugar in the urine was tested in all participants using dipsticks (Glukotest, Boehringer, Mannheim, Germany). All persons who tested positive and were unaware of having diabetes were invited to have glycosuria re-checked on a second urine sample a few hours later and, if still positive, in a urine sample collected on the next morning after an overnight fast (the later result was considered in such cases). This simple screening procedure was expected to provide only approximate estimates of diabetes prevalence as both a few false negative and false positive cases may be included. Yet, the prevalence of diabetes evaluated with this approach was very close to the figure obtained with the measurement of fasting glucose in 1994 i.e. $7.8 \%$ in men and $4.6 \%$ in women [25].

\section{Biochemical analyses}

On the inviting letter, no instruction on the need to be fasting was mentioned. Nevertheless most of the participants actually reported fasting. A venous blood sample was obtained from 8 a.m. and 2 p.m. and centrifugation took place within 2 hours of drawing and serum was kept frozen at $-20^{\circ} \mathrm{C}$. The analyses were performed at a laboratory in the University Policlinic, Lausanne, Switzerland and at the Canton Institute of Haematology and Clinical Chemistry, St. Gallen, Switzerland. Total cholesterol was determined enzymatically using a Boehringer test kit. HDL-cholesterol was measured similarly after precipitation with magnesium phosphotungstate. Triglycerides were analysed enzymatically using a Cobas-Mira centrifugal analyser (Wako Chemicals, USA). Uric acid was measured on a standard autoanalyzer. External controls for the laboratory determinations were regularly performed at the Swiss-Centre for Quality Control, by comparing the result of the analysis of a sample obtained in the requesting laboratory with the average of the results from all the participating laboratories.

\section{Statistical analysis}

All statistical analyses were carried out separately by sex using the Stata Software 6.0 (Stata Corporation, College Station, Texas). Linear and logistic regression techniques were used to determine the independent predictors of serum uric acid and hyperuricemia respectively. The various components of the metabolic syndrome, as well as the other established risk factors of uric acid (alcohol consumption, use of diuretics, etc.), were considered as potential explanatory variables in these models. Because data regarding the relationship of uric acid to cardiovascular disease is lacking in developing countries, ad-hoc criteria for hyperuricemia were adopted in this study. Values of uric acid above the sex-specific percentile 75 (i.e. $>460$ $\mu \mathrm{mol} / \mathrm{L}$ for men and $>296 \mu \mathrm{mol} / \mathrm{L}$ for women) were defined as high.

For continuous variables, the linear correlation coefficients with uric acid were first calculated and tested against zero. The statistically significant covariates were then included in a multivariate linear regression model and a stepwise backward selection procedure was used to determine which covariates contributed to the variation of uric acid independently of the others. Age, triglycerides, body mass index and alcohol consumption were retained in the final parsimonious regression model for both sexes. Robust estimators of the regression coefficients, based on the command "rreg" in the Stata software, were used because of some very high values of acid uric in the Seychelles. For categorical and binary variables, the strength of association with high uric acid was measured using the Mantel-Haenszel test for linear trend and the Pearson chisquare test respectively. A multivariate logistic regression model predicting high uric acid was developed resorting to the same stepwise method of variable selection.

\section{Results}

The characteristics of the participants are presented in Table 1. Smoking, alcohol consumption and high triglycerides levels were more common in men than in women. As shown in this table and in Figure 1, serum uric acid levels were significantly higher in men than in women $(\mathrm{p}<$ $0.01)$. When using the commonly accepted cut-off values for serum uric acid levels, i.e a serum uric acid $>420 \mu \mathrm{mol} /$ $\mathrm{L}$ in men and $>360 \mu \mathrm{mol} / \mathrm{L}$ in women [3], the prevalence of hyperuricemia would be $35.1 \%$ in men and $8.7 \%$ in women $(\mathrm{p}<0.01)$. In this analysis, however, we have used the sex-specific $75^{\text {th }}$ percentile which gives a cut-off at 460 $\mu \mathrm{mol} / \mathrm{L}$ for men and $296 \mu \mathrm{mol} / \mathrm{L}$ for women. Table 1 also shows the simple correlation coefficients between serum uric acid levels and the various cardiovascular risk factors in the population. In both sexes, serum triglycerides and serum uric acid levels were strongly correlated $(\mathrm{p}<0.001)$. In women, significant correlations $(\mathrm{p}<0.01)$ were also found with almost all metabolic parameters except for 
Table I: Mean levels, standard deviations and correlations with uric acid for selected cardiovascular risk factors by sex

\begin{tabular}{|c|c|c|c|c|c|c|c|}
\hline \multirow[b]{2}{*}{ Risk factor } & \multirow[b]{2}{*}{ unit } & \multicolumn{3}{|c|}{ Men $(n=482)$} & \multicolumn{3}{|c|}{ Women $(n=529)$} \\
\hline & & Mean & SD & Corr & Mean & SD & Corr \\
\hline Serum uric acid & $\mu \mathrm{mol} / \mathrm{l}$ & 408.7 & 175.3 & 1.000 & 264.3 & 80.0 & 1.000 \\
\hline Age & years & 44.7 & 11.5 & 0.142 & 44.5 & 11.5 & 0.357 \\
\hline Systolic BP & $\mathrm{mmHg}$ & 139.5 & 23.1 & 0.242 & 132.7 & 24.0 & 0.319 \\
\hline Diastolic BP & $\mathrm{mmHg}$ & 90.8 & 14.2 & 0.215 & 85.3 & 13.6 & 0.295 \\
\hline Total cholesterol & $\mathrm{mmol} / \mathrm{l}$ & 5.4 & 1.2 & 0.138 & 5.8 & 1.3 & 0.370 \\
\hline HDL-cholesterol & $\mathrm{mmol} / \mathrm{l}$ & 1.53 & 0.50 & -0.228 & 1.54 & 0.40 & -0.152 \\
\hline Triglycerides & $\mathrm{mmol} / \mathrm{l}$ & 1.48 & 1.17 & 0.734 & 1.16 & 0.68 & 0.528 \\
\hline Weight & $\mathrm{kg}$ & 70.0 & 12.5 & 0.254 & 68.0 & 15.2 & 0.290 \\
\hline Body mass index & $\mathrm{kg} / \mathrm{m}^{2}$ & 24.2 & 4.0 & 0.286 & 27.1 & 5.9 & 0.339 \\
\hline Waist & $\mathrm{cm}$ & 84.1 & 10.3 & 0.317 & 82.2 & 12.2 & 0.410 \\
\hline Waist-to-hip ratio & & 0.87 & 0.06 & 0.306 & 0.80 & 0.06 & 0.373 \\
\hline Alcohol intake & $\mathrm{ml} /$ day & 59.7 & 105.1 & 0.172 & 3.8 & 21.6 & 0.134 \\
\hline Smoking & $\%$ & 39.2 & - & - & 7.3 & - & - \\
\hline Treatment for hypertension & $\%$ & 9.0 & - & - & 13.0 & - & - \\
\hline History of diabetes & $\%$ & 5.0 & - & - & 6.0 & - & - \\
\hline
\end{tabular}

SD: standard-deviation; BP: blood pressure Corr: correlation coefficient with serum uric acid

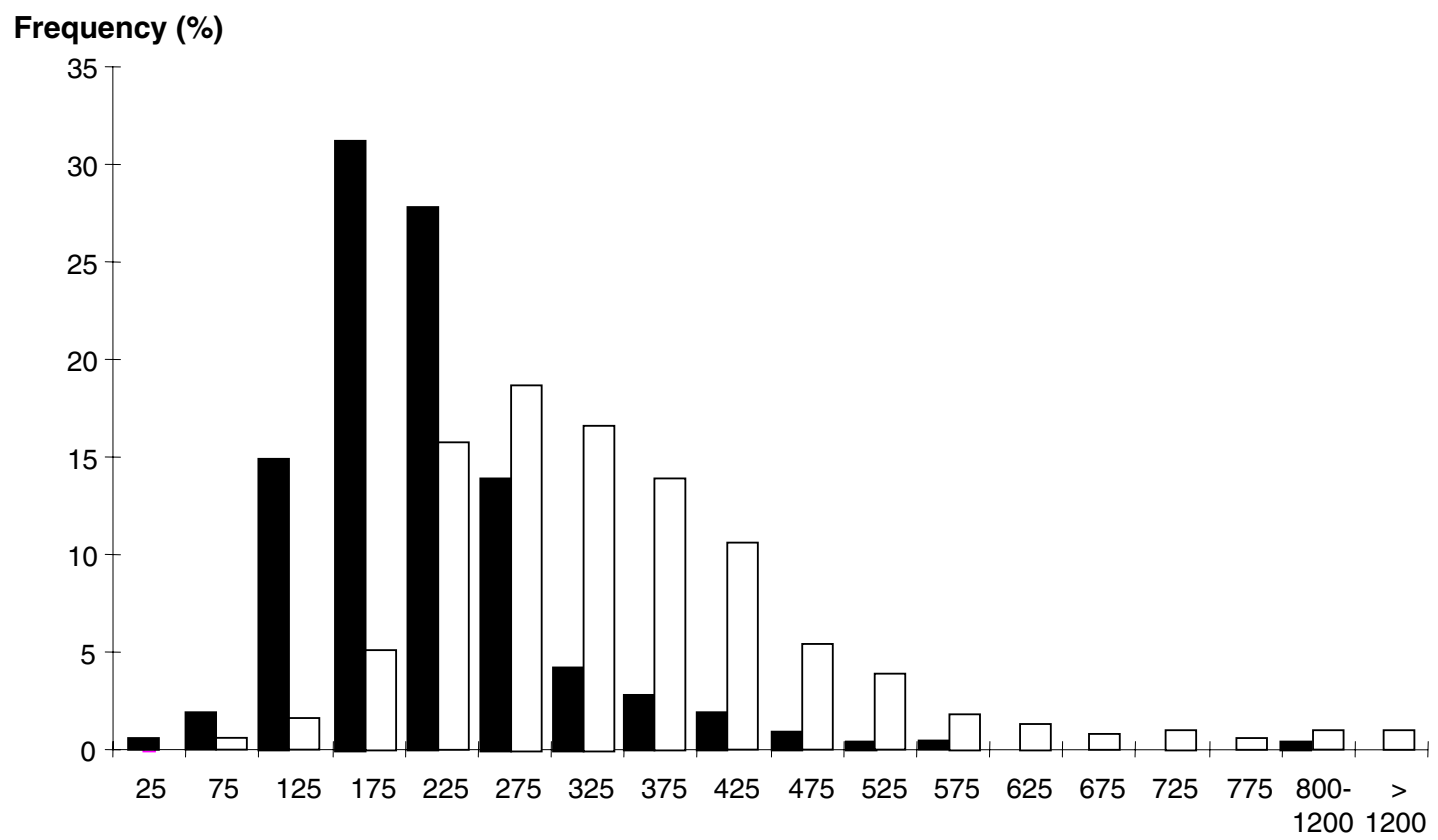

Serum uric acid in $\mu \mathrm{mol}$ (center of class)

Figure I

Distribution of serum uric acid by sex. White bars represent the distribution in men and black bars distribution in women. In men, the $25^{\text {th }}$ percentile of serum uric acid was $305 \mu \mathrm{mol} / \mathrm{L}$, the $50^{\text {th }}$ percentile $374 \mu \mathrm{mol} / \mathrm{L}$ and the $75^{\text {th }}$ percentile $460 \mu \mathrm{mol} / \mathrm{L}$. The respective figures in women were : $215 \mu \mathrm{mol} / \mathrm{L}, 253 \mu \mathrm{mol} / \mathrm{L}$ and $296 \mu \mathrm{mol} / \mathrm{L}$. 
alcohol consumption. In men, serum uric acid correlated with blood pressure, body weight, total cholesterol, waist and waist to hip ratio $(\mathrm{p}<0.01)$.

Table 2 shows the multivariate model linear regression model. Age, triglycerides, BMI, alcohol consumption and a treatment for hypertension were the major determinants of the variations in serum uric acid levels in both sexes. Table 3 presents the proportion of persons with high uric acid in sex-specific highest quartiles according to selected cardiovascular risk factors. As shown in this table, all metabolic parameters were strongly associated with serum uric acid levels. The effect of age was particularly prominent in women and the effect of alcohol consumption was more marked in men. Smoking had no effect on serum uric acid levels.
Table 4 shows the odds ratio for high uric acid levels according to different levels of age, triglycerides, waist, alcohol consumption and treatment of hypertension. As mentioned above, a high triglycerides level and the presence of hypertensive therapy was associated with a significant odd ratio of having an elevated serum uric acid level in this population. When excluding all subjects on antihypertensive therapy, only small changes were observed in the values of the regression coefficients. The most substantial change was found relative to the highest category of triglycerides in the logistic regression for men, the odd ratio decreasing from 37.5 before exclusion to 21.3 after exclusion. This suggests that antihypertensive therapy and particularly diuretics play a role in the association between a high triglyceride and a high uric acid level in men.

Table 2: Parsimonious robust multivariate linear regression model on serum uric acid by sex.

\begin{tabular}{|c|c|c|c|c|c|c|c|}
\hline \multirow[b]{2}{*}{ Explanatory variables } & \multirow[b]{2}{*}{ unit } & \multicolumn{3}{|c|}{ Men $(n=482)$} & \multicolumn{3}{|c|}{ Women $(n=529)$} \\
\hline & & Coeff & SD & $P$ & Coeff & SD & $P$ \\
\hline Age & years & 0.70 & 0.34 & 0.040 & 0.62 & 0.21 & 0.004 \\
\hline Triglycerides & $\mathrm{mmol} / \mathrm{l}$ & 99.34 & 3.38 & 0.000 & 46.54 & 3.56 & 0.000 \\
\hline Body mass index (BMI) & $\mathrm{kg} / \mathrm{m}^{2}$ & 2.08 & 1.01 & 0.040 & 2.83 & 0.41 & 0.000 \\
\hline Alcohol intake & $\mathrm{ml} /$ day & 0.16 & 0.04 & 0.000 & 0.21 & 0.10 & 0.041 \\
\hline Treatment for hypertension & $0 / 1$ & 45.93 & 13.66 & 0.001 & 35.96 & 7.23 & 0.000 \\
\hline Intercept & & 160.0 & 27.73 & 0.000 & 95.18 & 12.94 & 0.000 \\
\hline \% variation explained (R2) & & 0.488 & & & 0.471 & & \\
\hline
\end{tabular}

Table 3: Proportion of persons with high uric acid (i.e. in sex-specific highest quartile) according to selected cardiovascular risk factors, by sex

\begin{tabular}{|c|c|c|c|c|c|c|}
\hline & \multicolumn{3}{|c|}{ Men } & \multicolumn{3}{|c|}{ Women } \\
\hline & $\mathrm{n}$ & $\%$ & $P$ & $\mathrm{n}$ & $\%$ & $P$ \\
\hline \multicolumn{7}{|l|}{ Age group } \\
\hline $25-34$ & 115 & $13.9 \%$ & & 139 & $8.6 \%$ & \\
\hline $35-44$ & 113 & $24.8 \%$ & & 134 & $17.9 \%$ & \\
\hline $45-54$ & 130 & $33.1 \%$ & & 131 & $34.4 \%$ & \\
\hline $55-64$ & 124 & $26.6 \%$ & 0.009 & 125 & $40.8 \%$ & $<0.001$ \\
\hline \multicolumn{7}{|l|}{ Blood pressure } \\
\hline$<130 / 85 \mathrm{mmHg}$ & 117 & $15.4 \%$ & & 223 & $13.0 \%$ & \\
\hline$>130 / 85 \mathrm{mmHg}$ & 223 & $22.9 \%$ & & 209 & $30.6 \%$ & \\
\hline$>160 / 100 \mathrm{mmHg}$ & 142 & $35.9 \%$ & $<0.001$ & 97 & $40.2 \%$ & $<0.001$ \\
\hline \multicolumn{7}{|c|}{ Treatment for hypertension } \\
\hline no & 438 & $21.7 \%$ & & 460 & $20.4 \%$ & \\
\hline yes & 44 & $56.8 \%$ & $<0.001$ & 69 & $55.1 \%$ & $<0.001$ \\
\hline \multicolumn{7}{|l|}{ Total cholesterol } \\
\hline$<5.2 \mathrm{mmol} / \mathrm{l}$ & 231 & $19.0 \%$ & & 197 & $13.2 \%$ & \\
\hline $5.2-6.2 \mathrm{mmol} / \mathrm{l}$ & 135 & $28.1 \%$ & & 165 & $23.0 \%$ & \\
\hline
\end{tabular}


Table 3: Proportion of persons with high uric acid (i.e. in sex-specific highest quartile) according to selected cardiovascular risk factors, by sex (Continued)

\begin{tabular}{|c|c|c|c|c|c|c|}
\hline$>6.2 \mathrm{mmol} / \mathrm{l}$ & 116 & $32.8 \%$ & $<0.001$ & 167 & $40.7 \%$ & $<0.001$ \\
\hline \multicolumn{7}{|l|}{ HDL-Cholesterol } \\
\hline$>1.55 \mathrm{mmol} / \mathrm{l}$ & 201 & $15.4 \%$ & & 248 & $20.2 \%$ & \\
\hline $1.03-1.55 \mathrm{mmol} / \mathrm{l}$ & 208 & $26.4 \%$ & & 240 & $25.4 \%$ & \\
\hline$<1.03 \mathrm{mmol} / \mathrm{l}$ & 73 & $46.6 \%$ & $<0.001$ & 41 & $51.2 \%$ & $<0.001$ \\
\hline \multicolumn{7}{|l|}{ Triglycerides } \\
\hline$<1.0 \mathrm{mmol} / \mathrm{l}$ & 199 & $4.5 \%$ & & 273 & $11.4 \%$ & \\
\hline $1.0-1.7 \mathrm{mmol} / \mathrm{l}$ & 157 & $17.8 \%$ & & 168 & $28.0 \%$ & \\
\hline$>1.7 \mathrm{mmol} / \mathrm{l}$ & 126 & $65.9 \%$ & $<0.001$ & 88 & $61.4 \%$ & $<0.001$ \\
\hline \multicolumn{7}{|l|}{ Body mass index } \\
\hline$<25$ & 288 & $18.1 \%$ & & 207 & $11.6 \%$ & \\
\hline $25-30$ & 147 & $32.0 \%$ & & 168 & $23.8 \%$ & \\
\hline$>=30$ & 43 & $46.5 \%$ & $<0.001$ & 154 & $44.2 \%$ & $<0.001$ \\
\hline \multicolumn{7}{|l|}{ Waist } \\
\hline$<77 \mathrm{~cm}$ & 124 & $6.5 \%$ & & 202 & $7.9 \%$ & \\
\hline $77-88 \mathrm{~cm}$ & 177 & $24.3 \%$ & & 152 & $25.0 \%$ & \\
\hline$>88 \mathrm{~cm}$ & 179 & $38.0 \%$ & $<0.001$ & 171 & $45.6 \%$ & $<0.001$ \\
\hline \multicolumn{7}{|c|}{ Regular cigarette smoking } \\
\hline no & 293 & $27.3 \%$ & & 492 & $24.2 \%$ & \\
\hline yes & 189 & $21.2 \%$ & 0.128 & 37 & $35.1 \%$ & 0.138 \\
\hline \multicolumn{7}{|c|}{ Alcohol consumption } \\
\hline $0 \mathrm{ml} / \mathrm{j}$ & 234 & $20.9 \%$ & & 498 & $24.3 \%$ & \\
\hline$>0 \mathrm{ml} / \mathrm{j}$ & 248 & $28.6 \%$ & 0.051 & 31 & $35.5 \%$ & 0.163 \\
\hline \multicolumn{7}{|c|}{ History of diabetes } \\
\hline no & 458 & $24.0 \%$ & & 499 & $23.4 \%$ & \\
\hline yes & 24 & $41.7 \%$ & 0.051 & 30 & $50.0 \%$ & 0.001 \\
\hline Total & 482 & $24.9 \%$ & & 529 & $25.0 \%$ & \\
\hline
\end{tabular}

P Mantel-Haenszel test for linear association

Table 4: Parsimonious multivariate logistic regression model for predicting high uric acid (i.e. in sex-specific highest quartile) by sex

\begin{tabular}{|c|c|c|c|c|c|c|c|c|}
\hline & \multicolumn{4}{|c|}{ Men } & \multicolumn{4}{|c|}{ Women } \\
\hline & OR & $95 \% \mathrm{Cl}$ & & $\mathrm{P}$ & OR & $95 \% \mathrm{Cl}$ & & $P$ \\
\hline \multicolumn{9}{|l|}{ Age group } \\
\hline $25-34$ & 1.00 & -- & -- & -- & 1.00 & -- & -- & -- \\
\hline $35-44$ & 1.07 & 0.46 & 2.50 & 0.878 & 1.86 & 0.83 & 4.18 & 0.134 \\
\hline $45-54$ & 2.24 & 1.00 & 5.05 & 0.051 & 2.96 & 1.36 & 6.47 & 0.006 \\
\hline $55-64$ & 1.11 & 0.47 & 2.61 & 0.810 & 2.71 & 1.24 & 5.91 & 0.012 \\
\hline \multicolumn{9}{|c|}{ Treatment for hypertension } \\
\hline no & 1.00 & -- & -- & -- & 1.00 & -- & -- & -- \\
\hline yes & 4.98 & 2.12 & 11.68 & 0.000 & 2.43 & 1.31 & 4.51 & 0.005 \\
\hline \multicolumn{9}{|l|}{ Triglycerides } \\
\hline$<1.0 \mathrm{mmol} / \mathrm{l}$ & 1.00 & -- & -- & -- & 1.00 & -- & -- & -- \\
\hline $1.0-1.7 \mathrm{mmol} / /$ & 3.31 & 1.45 & 7.55 & 0.005 & 2.11 & 1.23 & 3.63 & 0.007 \\
\hline$>1.7 \mathrm{mmol} / \mathrm{l}$ & 37.49 & 16.09 & 87.33 & 0.000 & 7.50 & 3.95 & 14.23 & 0.000 \\
\hline
\end{tabular}


Table 4: Parsimonious multivariate logistic regression model for predicting high uric acid (i.e. in sex-specific highest quartile) by sex

\begin{tabular}{|c|c|c|c|c|c|c|c|c|}
\hline \multicolumn{9}{|l|}{ Waist } \\
\hline$<77 \mathrm{~cm}$ & 1.00 & -- & -- & -- & 1.00 & -- & -- & -- \\
\hline $77-88 \mathrm{~cm}$ & 2.90 & 1.16 & 7.27 & 0.023 & 2.87 & 1.46 & 5.63 & 0.002 \\
\hline$>88 \mathrm{~cm}$ & 1.96 & 0.78 & 4.90 & 0.152 & 4.24 & 2.18 & 8.23 & 0.000 \\
\hline \multicolumn{9}{|c|}{ Alcohol consumption } \\
\hline $0 \mathrm{ml} /$ day & 1.00 & -- & -- & -- & 1.00 & -- & -- & -- \\
\hline$>0 \mathrm{ml} /$ day & 1.55 & 0.90 & 2.68 & 0.113 & 2.38 & 0.97 & 5.85 & 0.059 \\
\hline
\end{tabular}

\section{Discussion}

The main observations of the present study are the following: firstly, the prevalence of hyperuricemia is high in our group of male Black subjects from the Seychelles. Secondly, significant relationships between serum uric and the various components of the metabolic syndrome were found in men as well as in women. Thirdly, a particularly strong association was found between serum uric acid levels and triglycerides. This association persisted after full adjustment in a multiple logistic model suggesting a close link between serum uric acid and serum triglycerides levels.

In accordance with previous studies, we found that serum uric acid levels are higher in men than in women, although uric acid levels in women tend to increase above the age of $50[8,26,27]$. These sex differences of serum uric acid levels and the increase after the menopause in females have been reported previously and attributed to the influence of sexual hormones [29]. We also found that male subjects have a higher prevalence of hyperuricemia than women. Black men in our study had unusually elevated serum uric acid levels, higher than those found in previous studies including Black populations [16,17]. A partial explanation for this could be the alcohol consumption. Alcohol consumption is significantly associated with elevated uric acid levels [29]. In our multivariate linear regression model, alcohol consumption contributes significantly to uric acid levels in men. Another important factor may be the use of antihypertensive agents such as diuretics which are known to increase serum uric acid levels [30,31]. In the Seychelles, diuretics belong to the most frequently prescribed first line therapy of essential hypertension. Hence, it is not surprising that anti-hypertensive therapy contributes significantly to the variations in serum uric acid in men as well as in women. Yet the strong association between serum uric acid and triglycerides persisted even after exclusion of all subjects receiving antihypertensive therapies.

Significant correlations were found between serum uric acid and several components of the metabolic syndrome, such as a higher BMI, waist-to-hip-ratio, blood pressure and lower HDL-cholesterol in both men and women. Several possible pathophysiological mechanisms have been evoked to explain these associations including insulin resistance $[13,14]$, the use of diuretics $[30,31]$ or impaired renal function accompanying hypertension [32,33]. Indeed the kidney seems to play an important role in the development of the metabolic syndrome [15]. Insulinresistant individuals secrete larger amounts of insulin in order to maintain an adequate glucose metabolism. The kidney which is not insulin-resistant responds to these high insulin levels by decreasing uric acid clearance, probably linked to insulin-induced urinary sodium retention [15]. Insulin resistance may increase blood pressure directly via enhanced proximal tubular sodium reabsorption $[34,35]$, or indirectly by the sympatho-adrenal system [36]. Thereby, the kidney has been implicated as the potential link between muscle insulin resistance and compensatory hyperinsulinemia and the development of hyperuricemia and eventually hypertension.

The most striking association found in our study is certainly the close relationship between serum triglycerides and serum uric acid levels and hyperuricemia. These observations were made in both sexes, with higher correlation levels in Black males. Interestingly the association was obtained even within the normal range of serum triglycerides. The correlation of triglycerides with uric acid has been found previously in several groups of patients $[11,13,16,17,37-41]$ including in patients with primary gout where a strong correlation $(\mathrm{r}=0.68, \mathrm{n}=44)$ was found between urinary uric acid excretion and serum triglycerides particularly among non-drinkers. A strong correlation $(\mathrm{r}=0.541)$ has even been reported in healthy subjects [38]. This association could have been explained by confounding factors such as the BMI or other associated variables as suggested previously. However, in our partially corrected correlations, the high statistical significance persisted although the coefficients were lower probably under the influence of age and BMI. In our robust multivariate linear regression model, age combined with BMI, triglycerides and anti-hypertensive therapy 
accounted for most of the variability of serum uric acid levels. The mechanism for the strong association of triglycerides values and serum uric acid levels are still not elucidated. Although, genetic factors have been associated with the concurrence of gout and hypertriglyceridemia $[42,43]$, most investigators tend to conclude that hyperuricemia and hypertriglyceridemia reflects more the lifestyle of the patient, as part of the metabolic syndrome, than genetic factors.

The interpretation of the present results is confronted by some limitations. Firstly, the data analysis was restricted to a cross-sectional study (the Seychelles Heart Study II). Only a prospective study could confirm the interdependencies of changes in the metabolic syndrome components and serum uric acid levels. Secondly, no serum insulin levels were measured as an index for insulin resistance. As insulin resistance is believed to play a major role in the metabolic syndrome, the inclusion of this variable in our statistical analysis would have been important. On the other hand it is unlikely that adjustment for insulin resistance could significantly influence our strongest association of serum uric acid and triglycerides, nor let disappear the differences found in men and women. Another limitation is that the study did not include individuals aged $>65$ years who may be exposed to a greater cardiovascular risk. Recent studies have shown that uric acid is also a prognostic marker in elderly patients with isolated systolic hypertension $[7,44]$. Finally the problem of over-adjustment when dealing with highly interrelated variables as those in the metabolic syndrome is well known.

\section{Conclusions}

In conclusion, our data show that hyperuricemia is very frequent in a developing country. Alcohol consumption and the use of diuretics appear to play an important role in mediating this hyperuricemia. However, hyperuricemia is also closely linked to the various components of the metabolic syndrome and in particular to serum triglycerides. Considering the rapidly increasing incidence of obesity and metabolic syndrome around the World and the potential link between hyperuricemia and coronary heart disease or stroke, more emphasis should be put on the evolving prevalence of hyperuricemia in developing countries.

Our results also provide some insights on the possible role of hyperuricemia as a risk factor in the development of cardiovascular complications. Indeed, several studies have found that uric acid is a prognostic marker for cardiovascular mortality and stroke [1-7]. Yet several other studies could not demonstrate a significant relationship between serum uric acid and cardiovascular diseases [810]. Experimentally, a longstanding hyperuricemia has been found to cause renal tubulo-interstitial injury which may lead to the development of hypertension and hence to cardiovascular complications [45]. In humans, even though raising serum uric acid concentrations in healthy people does not appear to impair cardiovascular function [46], elevated uric acid concentrations have been found to be a powerful risk marker in heart failure patients [47] and in elderly hypertensive patients $[7,44]$. The demonstration of a close relationship between serum uric acid and parameters of the metabolic syndrome reveals another possible link between serum uric acid and cardiovascular morbidity and mortality.

\section{Authors' contributions}

DC and VW have analyzed the database and produced the results. $\mathrm{PB}, \mathrm{FP}$ and $\mathrm{CS}$ have planned, organized and conducted the study in the Seychelles. WR has performed the uric acid measurements. $\mathrm{MB}$ has organized the analysis and $\mathrm{PB}, \mathrm{VW}$ and $\mathrm{MB}$ have written the paper. All authors read and approved the final manuscript.

\section{Acknowledgments}

This analysis was supported by an educational grant of Merck Sharp and Dohme AG, Switzerland

\section{References}

I. Gertler MM, Garn SM, Levine SA: Serum uric acid in relation to age and physique in health and coronary heart disease. Ann Intern Med I95I, 34:|42|-|43|.

2. Verdecchia P, Schillaci G, Reboldi GP, Santeusanio F, Porcellati C, Brunetti $P$ : Relation between serum uric acid and risk of cardiovascular disease in essential hypertension. Hypertension 2000, 36:1072-1078.

3. Fang J, Alderman MH: Serum uric acid and cardiovascular mortality. The NHANES I epidemiologic follow-up study, I97 I1992. JAMA 2000, 283:2404-24I0.

4. Liese AD, Hense HW, Löwel H, Döring A, Tietze M, Keil U: Association of serum uric acid with all-cause and cardiovascular disease mortality and incident myocardial infarction in the MONICA Augsburg cohort. Epidemiology 1999, 1 0:391-397.

5. Brand FN, McGee DL, Kannel WB, Stokes J III, Castelli WP: Hyperuricemia as a risk factor of coronary heart disease: the Framingham study. Am J Epidemiol 1985, I 2 I: I I- I8.

6. Wannamethee SG, Shaper AG, Whincup PH: Serum urate and the risk of major coronary heart disease events. Heart 1997 , 78(2): $147-153$.

7. Wang JG, Staessen JA, Fagard RH, Birkenhäger WH, Gong L, Liu L, for the Systollic Hypertension in China (Syst-China) Trial Collaborative Group: Hypertension 2001, 37:1069-1074.

8. Culleton BF, Larson MG, Kannel WB, Levy D: Serum uric acid and risk for cardiovascular disease and death: The Framingham Heart Study. Ann Intern Med 1999, I 3 1:7-13.

9. De Leeuw PW, Thijs L, Birkenhäger WH, Voyaki SM, Efstratopoulos AD, Fagard RH, Leonetti G, Nachev C, Petrie J, Rodicio JL, Rosenfeld JJ, Sarti C, Staessen J: Prognostic significance of renal function in elderly patients with isolated systolic hypertension: results from the Syst-Eur Trial. J Am Soc Nephrol 2002, I 3:22 1 3-2222.

10. Burnier M, Brunner HR: Is hyperuricemia a predictor of cardiovascular risk? Curr Opin Nephrol Hypertens 1999, 8: I67-I72.

II. Bonora E, Targher G, Zenere MB, Saggiani F, Cacciatori V, Tosi F, Travia D, Zenti MG, Branzi P, Santi L, Muggeo M: Relationship of uric acid concentration to cardiovascular risk factors in young men. The role of obesity and central fat distribution. The Verona Young Men Atherosclerosis Risk Factors Study. Int J Obes Relat Metab Disord 1996, 20:975-980.

12. Zavaroni I, Mazza S, Fantuzzi M, Dall'Aglio E, Bonora E, Delsignore R, Passeri M, Reaven GM: Changes in insulin and lipid metabolism 
in males with asymptomatic hyperuricemia. J Intern Med 1993, 234:25-30.

13. Vuorinen-Markkola $\mathrm{H}$, Yki-Järvinen $\mathrm{H}$ : Hyperuricemia and insulin resistance. J Clin Endocrinol Metab 1994, 78:25-29.

14. Facchini F, Ida Chen Y-D, Hollenbeck CB, Reaven GM: Relationship between resistance to insulin-mediated glucose uptake, urinary uric acid clearance and plasma uric acid concentration. JAMA I991, 266:3008-30II.

15. Reaven GM: The kidney: an unwilling accomplice in syndrome X. Am J Kidney Dis 1997, 30(6):928-931.

16. Rathmann W, Funkhouser E, Dyer AR, Roseman JM: Relations of hyperuricemia with the various components of the insulin resistance syndrome in young black and white adults: the CARDIA study. Coronary Artery Risk Development in Young Adults. Annals Epidemiol 1998, 8(4):250-26I.

17. Agamah ES, Srinivasan SR, Webber LS, Berenson GS: Serum uric acid and its relations to cardiovascular disease risk factors in children and young adults from a biracial community: The Bogalusa Heart Study. J Lab Clin Med I99I, I I 8:24I-249.

18. Li Y, Stamler J, Xiao Z, Folsom A, Tao S, Zhang H: Serum uric acid and its correlate in Chinese adult population, urban and rural, of Beijing. The PRC-USA Collaborative Study in Cardiovascular and Cardiopulmonary Epidemiology. Int J Epidemiol 1997, 26(2):288-296.

19. Lee J, Sparrow D, Vokonas PS, Landsberg L, Weiss ST: Uric acid and coronary heart disease risk: evidence for a role of uric acid in the obesity-insulin resistance syndrome. The Normative Aging Study. Am J Epidemiol 1995, 142(3):288-294.

20. Bruno G, Cavallo-Perin P, Bargero G, Borra M, Calvi V, D'Errico N, Deambrogio $P$, Pagano G: Prevalence and risk factors for microand macroalbuminuria in an Italian population-based cohort of NIDDM subjects. Diabetes Care 1996, I 9(I):43-47.

21. Rathmann W, Hauner H, Dannehl K, Gries FA: Association of elevated serum uric acid with coronary heart disease in diabetes mellitus. Diabete Metab 1993, 19:159-166.

22. Lehto S, Niskanen L, Rönnemaa T, Laakso M: Serum uric acid is a strong predictor of stroke in patients with non-insulindependent diabetes mellitus. Stroke 1998, 29:635-639.

23. Klein R, Klein BE, Cornoni JC, Maready J, Cassel JC, Tyroler HA: Serum uric acid: Its relationship to coronary heart disease risk factors and cardiovascular disease, Evans County, Georgia. Arch Intern Med 1973, I32:40I-I0.

24. Bovet P, Perret F, Shamlaye C, Darioli R, Paccaud F: The Seychelles heart Study II: methods and basic findings. Seychelles Medical \& Dental Journal 1997, 5:8-24.

25. Tappy L, Bovet P, Shamlaye C: Prevalence of diabetes and obesity in the adult population of the Seychelles. Diabet Med I99I, 8:448-52.

26. Mikkelsen WM, Dodge HJ, Valkenburg H: The distribution of serum uric acid values in a population unselected as to gout or hyperuricemia. Am J Med 1965, 39:242-25I.

27. Freedman DS, Williamson DF, Gunter EW, Byers T: Relation of serum uric acid to mortality and ischemic heart disease. The NHANES I epidemiologic follow-up study. Am J Epidemiol 1995 , | 41:637-644.

28. Nicholls A, Snaith ML, Scott JT: Effect of estrogen therapy on plasma and urinary levels of uric acid. BMJ 1973, I:449-45I.

29. Gordon T, Kannel WB: Drinking and its relation to smoking, blood pressure, blood lipids, and uric acid. The Framingham Study. Arch Int Med 1983, 143:1366-1374.

30. Savage PJ, Pressel SL, Curb JD, Schron EB, Applegate WB, Black HR, Cohen J, Davis BR, Frost P, Smith W, Gonzalez N, Guthrie GP, Oberman A, Rutan , Probstfiel JL, Stamler J: Influence of long-term, low-dose, diuretic-based, antihypertensive therapy on glucose, lipid, uric acid, and potassium levels in older men and women with isolated systolic hypertension. Arch Int Med 1998, I 58:74I-75I.

31. Bengtsson C: Elevated serum uric acid levels during treatment with antihypertensive drugs. Acta Med Scand Suppl 1979, 628:69-7I.

32. Messerli FH, Froehlich ED, Dreslinski GR, Suarez DH, Aristimuno GG: Serum uric acid in essential hypertension: an indicator of renal vascular involvement. Ann Intern Med 1980, 93:8I7-2I.

33. Cannon PJ, Stason WB, Demartini FE, Sommers SC, Laragh JH: Hyperuricemia in primary and renal hypertension. N Engl J Med 1966, 275:457-64.
34. Quinones GA, Natali A, Baldi S, Frascerra S, Sanna G, Ciociaro D, Ferrannini E: Effect of insulin on uric acid excretion in humans. Am J Physiol 1995, 268:EI-5.

35. Muscelli E, Natali A, Bianchi S, Bigazzi R, Galvan AQ, Sironi AM, Frascerra $S$, Ciociaro $D$, Ferrannini $E$ : Effect of insulin on renal sodium and uric acid handling in essential hypertension. $\mathrm{Am} J$ Hypertens 1996, 9:746-52.

36. Reaven GM, Lithell H, Landsberg L: Hypertension and associated metabolic abnormalities - the role of insulin resistance and the sympathoadrenal system. $N$ Engl J Med 1996, 334:374-38I.

37. Salomaa VV, Tuomilehto J, Jauhiainen M, Korhonen HJ, Stengard J, Uusitupa M, Pitkanen M, Penttila I: Hypertriglyceridemia in different degrees of glucose intolerance in a Finnish populationbased study. Diabetes Care 1992, 15:657-665.

38. Russo C, Olivieri O, Girelli D, Guarini P, Corrocher R: relationships between serum uric acid and lipids in healthy subjects. Prev Med 1996, 25:6II-616.

39. Matsubara K, Matsuzawa Y, Jiao S, Takama T, Kubo M, Tarui S: Relationship between hypertriglyceridemia and uric acid production in primary gout. Metabolism 1989, 38:698-70I.

40. Yano K, Hoads GG, Kagan A: Epidemiology of serum urate levels among 8000 Japanese-American men in Hawaii. J Chron Dis 1977, 30:17|-184.

4I. Goldbourt U, Medalie JH, Herman JB, Neufeld HN: Serum uric acid: correlation with biochemical, anthropometric, clinical and behavioral parameters in 10,000 Israeli men. J Chron Dis 1980, 33:435-443.

42. Ferns GA, Lanham J, Dieppe P, Galton DJ: A DNA polymorphism of an apoprotein gene associates with the hypertriglyceridemia of primary gout. Hum Genet 1988, 78:55-59.

43. Moriwaki Y, Tetsuya Y, Takahashi S, Tsutsumi Z, Higashino K: Apolipoprotein $E$ phenotypes in patients with gout: relation with hypertriglyceridemia. Ann Rheum Dis 1995, 54:35I-354.

44. Casiglia E, Spolaore P, Ginocchio G, Colangeli G, Di Menza G, Marchioro M, Mazza A, Ambrosio GB: Predictors of mortality in very old subjects aged 80 years or over. Eur J Epidemiol 1993, 9:577-586.

45. Johnson RJ, Kivlighn SD, Kim YG, Suga S, Fogo AB: Reappraisal of the pathogenesis and consequences of hyperuricemia in hypertension, cardiovascular disease and renal disease. $\mathrm{Am} \mathrm{J}$ Kidney Dis 1999, 33:225-234.

46. Waring WS, Adwani SH, Breukels O, Webb DJ, Maxwell SR: Hyperuricaemia does not impair cardiovascular function in healthy adults. Heart 2004, 90(2): I55- I59.

47. Anker SD, Doehner W, Rauchhaus M, Sharma R, Francis D, Knosalla C, Davos CH, Cicoira M, Shamim W, Kemp M, Segal R, Osterziel KJ, Leyva F, Hetzer R, Ponikowski P, Coats AJ: Uric acid and survival in chronic heart failure: validation and application in metabolic, functional, and hemodynamic staging. Circulation 2003, 107(15): 1991-1997.

\section{Pre-publication history}

The pre-publication history for this paper can be accessed here:

\section{http://www.biomedcentral.com/1471-2458/4/9/prepub}

Publish with Biomed Central and every scientist can read your work free of charge

"BioMed Central will be the most significant development for disseminating the results of biomedical research in our lifetime. "

Sir Paul Nurse, Cancer Research UK

Your research papers will be:

- available free of charge to the entire biomedical community

- peer reviewed and published immediately upon acceptance

- cited in PubMed and archived on PubMed Central

- yours - you keep the copyright
BioMedcentral 